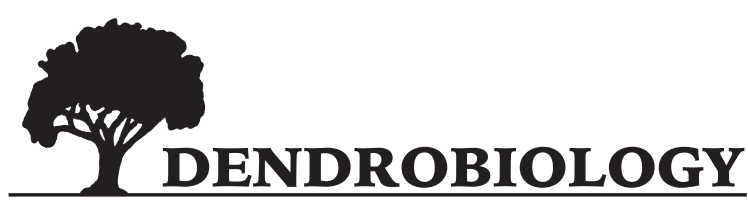

2016, vol. 76, 137-144

http://dx.doi.org/10.12657/denbio.076.013

\author{
Piotr Łakomy, Hanna Kwaśna, Robert Kuźmiński, \\ Anna Napierała-Filipiak, Maciej Filipiak, Katarzyna Behnke, \\ Jolanta Behnke-Borowczyk
}

\section{Investigation of Ophiostoma population infected elms in Poland}

Received: 24 January 2016; Accepted: 2 August 2016

\begin{abstract}
Dutch elm disease (DED) still occurs in Poland. Previous studies confirmed occurring O. ulmi and two subspecies of $O$. novo-ulmi: subsp. novo-ulmi and subsp. amerciana. In this study the population of Ophiostoma occurred in Poland was investigated. The disease incidence was investigated on elms growing in 39 locations. The pathogen's mycelium was isolated from elm branches and twigs collected from 22 plots. The disease symptoms were noted in $5 \%$ to $35 \%$ trees. Fungi were identified based on the PCR amplification of the ITS $1 / 2$ rDNA together with phylogenetic analysis of this region. Ophiostoma novo-ulmi was the only agent caused DED on Ulmus glabra, U. minor and U. laevis. There were no genetic diversity of O. novo-ulmi Polish population in analyzed ITS region. All kind of specific symptoms and disease intensity occurred independently on elm species and host age. Ulmus minor was infested most sever among the three elms species.
\end{abstract}

Keywords: Ophiostoma novo-ulmi, Dutch elm disease, Ulmus

Addresses: P. Łakomy, H. Kwaśna, K. Behnke, J. Behnke-Borowczyk, Poznan University of Life Sciences, Faculty of Forestry, Department of Forest Pathology, Poland, e-mail: plakomy@up.poznan.pl

R. Kuźmiński, Poznan University of Life Sciences, Faculty of Forestry, Department of Forest Entomology, Poland

A. Napierała-Filipiak, M. Filipiak, Institute of Dendrology Polish Academy of Science, Kórnik, Poland M. Filipiak, Institute of Landscape Architecture, Wrocław University of Environmental and Life Sciences, Wrocław, Poland

\section{Introduction}

Dutch elm disease (DED) causes wilting and decay of twigs and branches and in many cases death of native Ulmus species in Europe, North America and Asia. The disease is due to two pathogenic fungi Ohiostoma ulmi (Buisman) Nannf. and Ophiostoma novo-ulmi Brasier (Brasier, 1991; Mańka, 2005). The first notice of this disease in Europe was described in the beginning of XX century. In that time, O. ulmi was the agent of the diseases. Nowadays Dutch elm diseases mainly causes $\mathrm{O}$. novo-ulmi infecting and killing elms independently of the tree age. This species is much more pathogenic than O. ulmi (Brasier, 1996). Ophiostoma novo-ulmi was divided into two subspecies O. novo-ulmi subsp. novo-ulmi and subsp. americana (Brasier \& Kirk, 2001). Pathogens are transferred from tree to tree by insect vectors. Six species of Scolytus were found as a Ophiostoma vectors - Scolytus scolytus (Fabricius), S. multistriatus (Marsham), S. schevyrewi Semenov, S. kirschii Skalitzky, S. pygmae- 
us (Fabricius) and Scolytus laevis Chapuis (Webber, 1990; Faccoli \& Battisti, 1997; Solheim et al., 2011; Jacobi et al., 2013). In Poland both pathogens O. ulmi and O. novo-ulmi have been found as agents of Dutch elm disease (Guździoł et al., 2004).

The aim of this study was to define the Ophiostoma species occurring in Poland nowadays. On the base of symptoms frequency, the disease incidence was described on the three elm species Ulmus glabra Huds, $U$. laevis Pall. and U. minor Mill.

\section{Materials and methods}

The observations were carried out on 39 plots located in pure or mixed elm stands and incidentally along roads or in parks and among fields (Table 1).

Table 1. Localization of investigated plots

\begin{tabular}{|c|c|c|c|}
\hline Plot no & Location & GPS guidance & Site type \\
\hline 1 & Miękinia & $\begin{array}{l}\mathrm{N}^{\prime} 1^{\circ} 11^{\prime} 25.6049^{\prime \prime} \\
\mathrm{E} 16^{\circ} 44^{\prime} 10.3042^{\prime \prime}\end{array}$ & Alluvial forest \\
\hline 2 & Babki & $\begin{array}{l}\mathrm{N} 52^{\circ} 1^{\prime} 25.4191^{\prime \prime} \\
\mathrm{E} 17^{\circ} 5^{\prime} 29.5212^{\prime \prime}\end{array}$ & Park \\
\hline 3 & Miękinia & $\begin{array}{l}\mathrm{N} 51^{\circ} 11^{\prime} 25.6049^{\prime \prime} \\
\mathrm{E} 16^{\circ} 44^{\prime} 44.4036^{\prime \prime}\end{array}$ & Alluvial forest \\
\hline 4 & Durowo & $\begin{array}{l}\text { N525ㅇ' } 23.561^{\prime \prime} \\
\mathrm{E} 17^{\circ} 12^{\prime} 47.237^{\prime \prime}\end{array}$ & Along road \\
\hline 5 & Szczecinek & $\begin{array}{l}\text { N53 } 42^{\prime} 14.923^{\prime \prime} \\
\text { E16 } 39^{\prime} 55.321^{\prime \prime}\end{array}$ & Deciduous forest \\
\hline 6 & Choszczno & $\begin{array}{l}\text { N53 } 13^{\prime} 19.891^{\prime \prime} \\
\mathrm{E} 15^{\circ} 25^{\prime} 2.6^{\prime \prime}\end{array}$ & Deciduous forest \\
\hline 7 & Kolbudy & $\begin{array}{l}\text { N54 } 14^{\circ} 34.214^{\prime \prime} \\
\mathrm{E} 18^{\circ} 25^{\prime} 12.323^{\prime \prime}\end{array}$ & Deciduous forest \\
\hline 8 & Oleśnica & $\begin{array}{l}\text { N51 } 15^{\prime} 28.353^{\prime \prime} \\
\mathrm{E} 17^{\circ} 25^{\prime} 33.471^{\prime \prime}\end{array}$ & Deciduous forest \\
\hline 9 & Piaski & $\begin{array}{l}\text { N52 } 2^{\circ} 5^{\prime} 34.7516^{\prime \prime} \\
\mathrm{E} 16^{\circ} 59^{\prime} 16.8787^{\prime \prime}\end{array}$ & Alluvial forest \\
\hline 10 & Legnica & $\begin{array}{l}\text { N51ํ1' } 32.064^{\prime \prime} \\
\text { E16 } 16^{\circ} 37.492^{\prime \prime}\end{array}$ & Deciduous forest \\
\hline 11 & Wałbrzych & $\begin{array}{l}\text { N50 44' 7.171" } \\
\text { E16 } 16^{\circ} 57.786^{\prime \prime}\end{array}$ & Deciduous forest \\
\hline 12 & Wałbrzych & $\begin{array}{l}\text { N50 } 46^{\prime} 18.38^{\prime \prime} \\
\text { E16 } 17^{\prime} 3.774^{\prime \prime}\end{array}$ & Park \\
\hline 13 & Ośno Lubuskie & $\begin{array}{l}\text { N52 } 28^{\prime} 43.556^{\prime \prime} \\
\text { E14 }^{\circ} 52^{\prime} 45.847^{\prime \prime}\end{array}$ & Deciduous forest \\
\hline 14 & Oborniki Śląskie & $\begin{array}{l}\text { N51 }{ }^{\circ} 23^{\prime} 44.1853^{\prime \prime} \\
E 16^{\circ} 59^{\prime} 32.2047^{\prime \prime}\end{array}$ & Deciduous forest \\
\hline 15 & Grotniki & $\begin{array}{l}\text { N51 } 51^{\circ} 53^{\prime} 57.449^{\prime \prime} \\
\mathrm{E} 19^{\circ} 19^{\prime} 30.813^{\prime \prime}\end{array}$ & Deciduous forest \\
\hline 16 & Grotniki & $\begin{array}{l}\text { N51 } 51^{\circ} 37.619^{\prime \prime} \\
\text { E19 } 19^{\circ} 32.16^{\prime \prime}\end{array}$ & Deciduous forest \\
\hline 17 & Piaski & $\begin{array}{l}\text { N51 }{ }^{\circ} 7^{\prime} 20.8048^{\prime \prime} \\
\mathrm{E} 22^{\circ} 50^{\prime} 38.9283^{\prime \prime}\end{array}$ & Deciduous forest \\
\hline 18 & Złoczew & $\begin{array}{l}\text { N51 }{ }^{\circ} 26^{\prime} 51.01^{\prime \prime} \\
\mathrm{E} 18^{\circ} 40^{\prime} 34.845^{\prime \prime}\end{array}$ & Deciduous forest \\
\hline 19 & Rudy & $\begin{array}{l}\text { N50 } 11^{\prime} 22.1586^{\prime \prime} \\
\text { E18 } 27^{\circ} 17.2998^{\prime \prime}\end{array}$ & Deciduous forest \\
\hline 20 & Babki & $\begin{array}{l}\text { N52 } 22^{\prime} 40.7489^{\prime \prime} \\
\mathrm{E} 17^{\circ} 4^{\prime} 15.9815^{\prime \prime}\end{array}$ & Along road \\
\hline
\end{tabular}

All elm species (U. minor, U. glabra and U. laevis) occurring in Poland were investigated. The incidence of disease symptoms was also noticed. The dead or dying branches were collected from diseased elms. The cross cutting of each branch revealed a ring of dark brown staining in the outer wood. The samples were collected from 1-3 elms and depended on the number of trees occurred in each localization. In addition three diseased branches, $30 \mathrm{~cm}$ long, were cut from each tree. Samples of $U$. minor were collected from $37 \%$ of plots, U. glabra from $33 \%$ and samples of $U$. laevis were cut from $30 \%$ of plots. In the laboratory, branches were divided to $1 \mathrm{~cm}$ long pieces. Each wood sample was surface disinfected in sodium hypochlorite $(2 \% \mathrm{NaOCl})$ for 1 minute and rinsed three times in sterile and demineralized water for 10 minutes (Kwaśna \& Siwecki, 2002). After drying,

\begin{tabular}{|c|c|c|c|}
\hline Plot no & Location & GPS guidance & Site type \\
\hline 21 & Rudy & $\begin{array}{l}\text { N50 } 10^{\prime} 39.3661^{\prime \prime} \\
\text { E1 } 8^{\circ} 30^{\prime} 0.5494^{\prime \prime}\end{array}$ & Deciduous forest \\
\hline 22 & Żmigród & $\begin{array}{l}\text { N51 } 1^{\circ} 28^{\prime} 31.7328^{\prime \prime} \\
\mathrm{E} 16^{\circ} 55^{\prime} 3.5065^{\prime \prime}\end{array}$ & Alluvial forest \\
\hline 23 & Sulechów & $\begin{array}{l}\mathrm{N} 52^{\circ} 2^{\prime} 19.7075^{\prime \prime} \\
\mathrm{E} 15^{\circ} 33^{\prime} 1.1647^{\prime \prime}\end{array}$ & Alluvial forest \\
\hline 24 & Rudka & $\begin{array}{l}\text { N52 9' } 12.7654^{\prime \prime} \\
\text { E21 } 41^{\circ} \text { ' 39.4923" }\end{array}$ & Among fields \\
\hline 25 & Rudka & $\begin{array}{l}\text { N52 } 2^{\circ} 11^{\prime} 7.9888^{\prime \prime} \\
\text { E2 } 1^{\circ} 53^{\prime} 17.0216^{\prime \prime}\end{array}$ & Deciduous forest \\
\hline 26 & Białowieża & $\begin{array}{l}\mathrm{N} 52^{\circ} 42^{\prime} 34.6814^{\prime \prime} \\
\mathrm{E} 23^{\circ} 49^{\prime} 33.7793^{\prime \prime}\end{array}$ & Alluvial forest \\
\hline 27 & $\begin{array}{l}\text { Czarna } \\
\text { Białostocka }\end{array}$ & $\begin{array}{l}\mathrm{N}^{\prime} 3^{\circ} 19^{\prime} 27.3738^{\prime \prime} \\
\mathrm{E}^{\circ} 3^{\circ} 17^{\prime} 10.8472^{\prime \prime}\end{array}$ & Deciduous forest \\
\hline 28 & Zwierzyniec & $\begin{array}{l}\text { N50 } 36^{\prime} 50.544^{\prime \prime} \\
\text { E22 } \\
\end{array}$ & Deciduous forest \\
\hline 29 & Chojnów & $\begin{array}{l}\mathrm{N}^{\prime} 1^{\circ} 18^{\prime} 53.6627^{\prime \prime} \\
\mathrm{E} 15^{\circ} 58^{\prime} 58.2294^{\prime \prime}\end{array}$ & Along road \\
\hline 30 & Chojnów & $\begin{array}{l}\mathrm{N}^{5} 1^{\circ} 1^{\prime} 9^{\prime} 23.7885^{\prime \prime} \\
\mathrm{E} 15^{\circ} 54^{\prime} 39.9133^{\prime \prime}\end{array}$ & Among fileds \\
\hline 31 & Dobieszyn & $\begin{array}{l}\text { N51 } 1^{\circ} 37^{\prime} 18.5189^{\prime \prime} \\
\text { E21 }{ }^{\circ} 9^{\prime} 45.1868^{\prime \prime}\end{array}$ & Deciduous forest \\
\hline 32 & Grójec & $\begin{array}{l}\text { N51 } 51^{\prime} 44.1218^{\prime \prime} \\
\mathrm{E} 20^{\circ} 53^{\prime} 50.5916^{\prime \prime}\end{array}$ & Along road \\
\hline 33 & Chojnów & $\begin{array}{l}\mathrm{N}^{\prime} 1^{\circ} 18^{\prime} 53.6627^{\prime \prime} \\
\mathrm{E} 15^{\circ} 58^{\prime} 58.2294^{\prime \prime}\end{array}$ & Among fields \\
\hline 34 & Kwidzyń & $\begin{array}{l}\text { N53 } 43^{\prime} 1.009^{\prime \prime} \\
\text { E18 } 47^{\prime} 57.319^{\prime \prime}\end{array}$ & Deciduous forest \\
\hline 35 & Srokowo & $\begin{array}{l}\text { N54 } 14^{\prime} 52.426^{\prime \prime} \\
\mathrm{E} 21^{\circ} 34^{\prime} 14.003^{\prime \prime}\end{array}$ & Deciduous forest \\
\hline 36 & Świdnik & $\begin{array}{l}\text { N51 } 15^{\prime} 7.931^{\prime \prime} \\
\mathrm{E} 22^{\circ} 43^{\prime} 4.094^{\prime \prime}\end{array}$ & Deciduous forest \\
\hline 37 & Dukla & $\begin{array}{l}\mathrm{N} 49^{\circ} 32^{\prime} 1.074^{\prime \prime} \\
\mathrm{E} 21^{\circ} 40^{\prime} 28.006^{\prime \prime}\end{array}$ & Deciduous forest \\
\hline 38 & Ustroń & $\begin{array}{l}\text { N49 } 43^{\prime} 44.264^{\prime \prime} \\
\mathrm{E} 18^{\circ} 50^{\prime} 1.657^{\prime \prime}\end{array}$ & Deciduous forest \\
\hline 39 & Łopuchówko & $\begin{array}{l}\text { N52 } 22^{\circ} 46.5673^{\prime \prime} \\
\text { E16 } 49^{\circ} 32.5159^{\prime \prime}\end{array}$ & Along road \\
\hline
\end{tabular}


the wood pieces were divided for $4-5$ pieces and put on SNA (glucose, $0.2 \mathrm{~g}$, sucrose $0.2 \mathrm{~g}, \mathrm{KH}_{2} \mathrm{PO}_{4}, 1 \mathrm{~g}$, $\mathrm{KNO}_{3}, 1 \mathrm{~g}, \mathrm{MgSO}_{4} \times 7 \mathrm{H}_{2} \mathrm{O}, 0.5 \mathrm{~g}$, agar, $15 \mathrm{~g}$, streptomycin, $0.001 \mathrm{~g}$, distilled water, 1 1) (Nirenberg, 1976) and PDA (potato-dextrose agar) medium in Petri dishes. After 3-5 days of incubation in the dark and in $25^{\circ} \mathrm{C}$ temperature wood pieces were investigated for a presence of conidial stage of Ophiostoma fungi with the aid of micromorphological features of colonies.

The cultures was cultivated on liquid medium (10 $\mathrm{g} \mathrm{NaCl}, 10 \mathrm{~g}$ tryptone, $5 \mathrm{~g}$ yeast extract, distilled water) for two weeks. The mycelium was harvested with a strainer, lyophilized and ground to a fine powder in liquid nitrogen. Total genomic DNA was extracted from mycelium using the Bead-Beat Micro Gravity kit (A\&A BIOTECHNOLOGY, Gdynia). PCR amplification of the ITS $1 / 2$ rDNA was done with DNA diluted $\left(10^{-2}\right)$ in deionized water. Primers used were ITS1-F (5'CTT GGT CAT TTA GAG GAA GTA A) (Gardes \& Bruns, 1993) as well as ITS4 (5' TCCTCCGCTTATTGATATGC 3') (White et al., 1990). Each $25 \mu$ l PCR mixture consisted of $0.2 \mu \mathrm{mol} \mathrm{L}^{-1}$ of each primer, 0.25 $\mathrm{U}$ of Taq polymerase (MBI Fermentas, St. Leon-Rot, Germany), buffer (10 mmol L ${ }^{-1}$ Tris-HCl pH 8.8, 50 mmol L ${ }^{-1} \mathrm{KCl}, 0.08 \%$ Nonidet P-40, $0.1 \mathrm{mg} \mathrm{ml}-1$ BSA, $1.5 \mathrm{mmol} \mathrm{L}^{-1} \mathrm{MgCl}_{2}$ ), $0.2 \mathrm{mmol} \mathrm{L}-1$ deoxyribonucleoside triphosphates (dNTPs) and $2 \mu$ l of DNA. PCR conditions included an initial denaturation step at $94^{\circ} \mathrm{C}$ for $10 \mathrm{~min}$, followed by 30 cycles of $94^{\circ} \mathrm{C}$ for $30 \mathrm{~s}, 42^{\circ} \mathrm{C}$ for $1 \mathrm{~min}$ and $72^{\circ} \mathrm{C}$ for $2 \mathrm{~min}$. This was followed by a final extension of $72^{\circ} \mathrm{C}$ for $10 \mathrm{~min}$. The PCR products were checked by electrophoresis of $5 \mu \mathrm{l}$ of the product in a $1 \%$ agarose gel containing ethidium bromide $\left(0.5 \mathrm{mg} \mathrm{ml}^{-1}\right)$. PCR products were purified using the MinElute PCR purification kit (Qiagen, Crawley, UK). The amplified fragments were sequenced at the Centre of DNA Studies in Poznań, Poland. Sequences were identified by comparison with reference sequences in the NCBI GenBank.

Sequences were obtained after sequencing together with referenced sequences and sequences of O. ulmi, O. himal-ulmi Brasier \& M.D. Mehrotra, $O$. piceae (Münch) Syd. \& P. Syd. In addition sequence of Diaporthe eres Nitschke were used to outgroup. This species was chose as a outgroup, because it was isolated from branches previously infected by Ophiostoma. The aligment of $484 \mathrm{pz}$ length was generated automatically with the aid of Clustal X version 1.8 (Thompson et al., 1997). The identical sequences were removed by manual operation and remained one which was representative. Next the phylogenetic analysis was carried out on the base of neighbor-joning method. To confirm reliability of tree clusters, the Bootstrap was used with 1000 replications. The level of phylogenetic analysis was accepted on $>60 \%$. The analysis was carried out with the aid of MEGA 5.2 program (Tamura et al., 2011).

\section{Results}

The symptoms of DED were observed on every investigated plots. Disease appeared on all elm species and occurred with different intensity. Both rapid and slow disease course was noticed. In the rapid course of DED leaves wilted, dried out rapidly, turn dull green, died and remain attached to the twigs for some weeks. In slow case wilting leaves curl, turn yellow and brown and fall of after death. In particular on the same crowns of mature $U$. laevis both disease courses were observed in the same time. Ulmus minor was the most suffered species by DED and U. laevis was the less diseased. The disease incidence on plots differ from $5 \%$ to $35 \%$ of all elms specimens. In particular tree the simple branches were infested, but in the severe crown infestation was observed, even up to $70 \%$ of dead branches. Such DED intensity was observed independently of elm species and plot localization. Moreover in all cases the dying process was noted independently of elm species and tree age.

Isolates of Ophiostoma were collected from twigs and branches of elms from 19 locations. In rest (52\%) samples the mycelium of others fungi was isolated from twigs and branches with DED symptoms. Alive pathogen's mycelium was noted in 55\% of branch samples. Ophiostoma was isolated from all elm species, in addition from $U$. laevis the pathogen's mycelium was obtained from 6 locations (12 isolates), from U. minor from 9 locations (18 isolates) and from U. glabra the mycelium was isolates from 6 locations (11 isolates). On two localities Sulechów (23) and Łopuchówko (39) U. minor and U. laevis were infested by pathogen in the same time. On the base of molecular analysis all isolates belonged to the only species - Ophiostoma novo-ulmi (Fig. 1, Table 2). All isolates produced white mycelium and morphologically were identical. The Sporothrix conidiophores appeared abundantly on aerial hyphae especially growing on the SNA medium.

In ITS region there was detected a very low genetic diversity. Only two isolates had simple nucleotides changes. In isolate 39.3 at position 158 the adenine was altered by cytosine and in isolate 39.4 at position 260 the adenine was altered by thymine and at position 360 guanine was altered by cytosine. The rest isolates were identical. The isolate 24.1 was chosen as a representative sequence. All analyzed sequences were located in one cluster with $O$. novo-ulmi sequences. Other Ophiostoma isolates were located outside the $O$. novo-ulmi cluster. Diaporthe eres was made as an external group (Fig. 2).

Branches, inside which the O. novo-ulmi was not active, were colonized by other fungi. Partially there were mitosporic fungi from genus Penicillium or Trichoderma, but in many cases the weak pathogens, which cause the bark blight or branches decline occurred. 


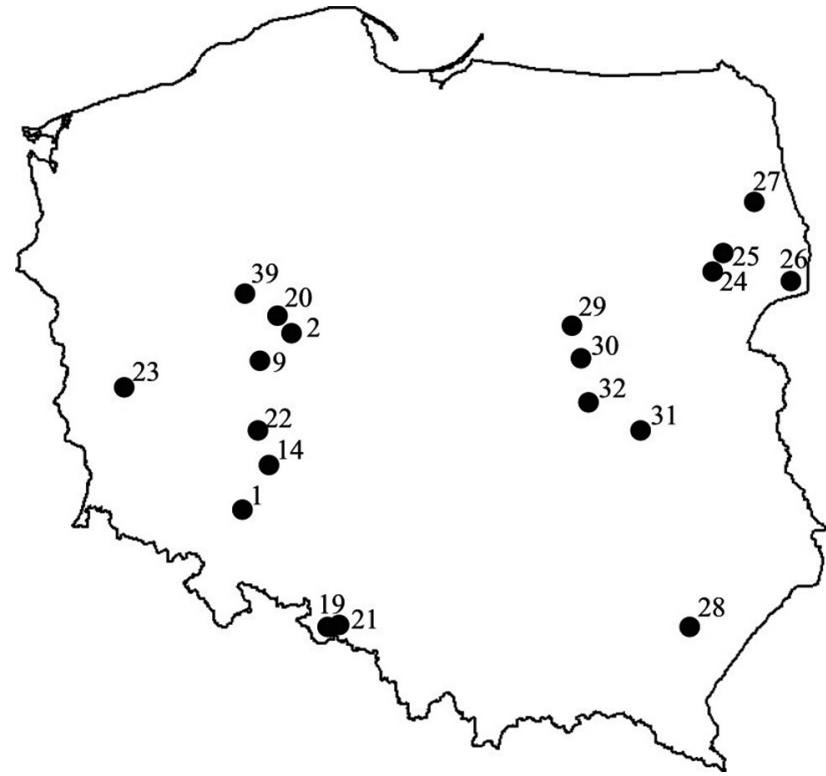

Fig. 1. Geographical distribution of Ophiostoma novo-ulmi isolates

Seven species were identified Gibberella avenacea R.J. Cook, Diaporthe eres, Diaporthe melonis Beraha \& M.J. O'Brien, Aureobasidium pullulans (de Bary \& Löwenthal) G. Arnaud, Nectria nigrescens Cooke, Gibberella baccata (Wallr.) Sacc., Fusarium sambucinum Fuckel.

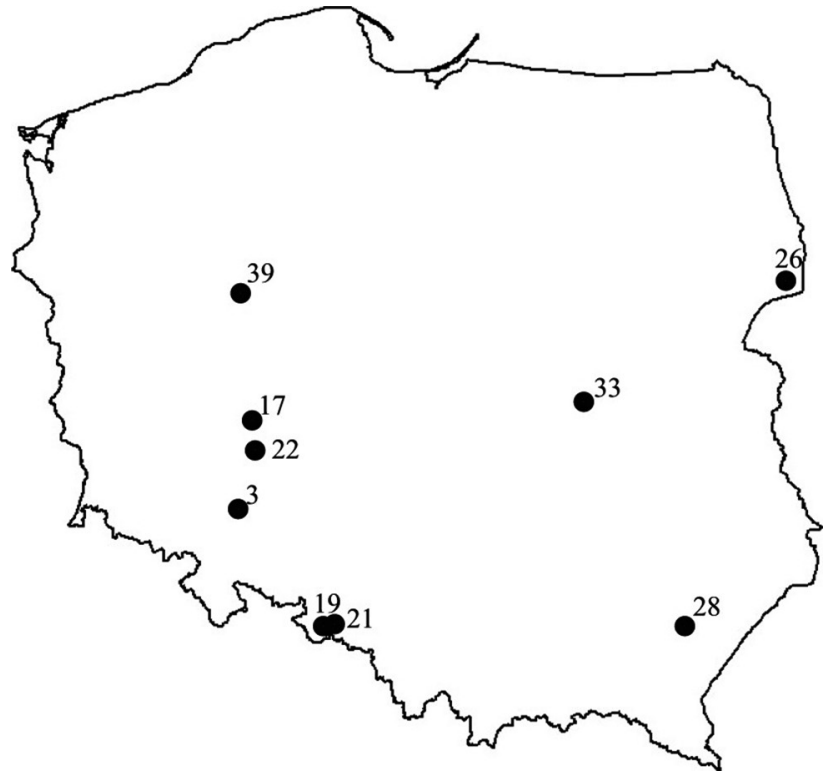

Fig. 3. Geographical distribution of other fungi isolated from elm branches

The Diaporthe eres was the most often species isolated from branches (35\%) (Fig. 3, Table 3).

Branches of $U$. laevis were colonized the most frequently by other fungi (64\%) in comparison to other elm species ( $18 \%$ of each).

Table 2. Origin of Ophiostoma isolates

\begin{tabular}{|c|c|c|c|c|c|c|}
\hline Plot no. & Location & Host & Isolates no. & Molecular identification & $\begin{array}{c}\text { Probability } \\
\%\end{array}$ & $\begin{array}{c}\text { No of referring } \\
\text { sequence at } \\
\text { NCBI }\end{array}$ \\
\hline 1 & Miękinia & Ulmus minor & 1 & Ophiostoma novo-ulmi & 100 & $\mathrm{KJ} 677112$ \\
\hline 2 & Babki & Ulmus glabra & 1 & Ophiostoma novo-ulmi & 100 & KJ677112 \\
\hline 9 & Piaski & Ulmus minor & 1 & Ophiostoma novo-ulmi & 100 & KJ677112 \\
\hline 14 & Oborniki Śląskie & Ulmus minor & 1 & Ophiostoma novo-ulmi & 100 & KJ677112 \\
\hline 19 & Rudy & Ulmus glabra & 1 & Ophiostoma novo-ulmi & 100 & KJ677112 \\
\hline 20 & Babki & Ulmus glabra & 4 & Ophiostoma novo-ulmi & 100 & $\mathrm{KJ} 677112$ \\
\hline 21 & Rudy & Ulmus laevis & 1 & Ophiostoma novo-ulmi & 100 & KJ677112 \\
\hline 22 & Żmigród & Ulmus minor & 1 & Ophiostoma novo-ulmi & 99 & KJ677112 \\
\hline \multirow{2}{*}{23} & \multirow{2}{*}{ Sulechów } & Ulmus laevis & 1 & Ophiostoma novo-ulmi & 100 & KJ677112 \\
\hline & & Ulmus minor & 1 & Ophiostoma novo-ulmi & 99 & KJ677112 \\
\hline \multirow{2}{*}{24} & \multirow{2}{*}{ Rudka } & \multirow{2}{*}{ Ulmus minor } & 2 & Ophiostoma novo-ulmi & 100 & KJ677112 \\
\hline & & & 2 & Ophiostoma novo-ulmi & 100 & KJ677112 \\
\hline 25 & Rudka & Ulmus laevis & 1 & Ophiostoma novo-ulmi & 100 & KJ677112 \\
\hline 26 & Białowieża & Ulmus glabra & 2 & Ophiostoma novo-ulmi & 100 & KJ677112 \\
\hline 27 & Czarna Białostocka & Ulmus glabra & 2 & Ophiostoma novo-ulmi & 100 & KJ677112 \\
\hline 28 & Zwierzyniec & Ulmus glabra & 1 & Ophiostoma novo-ulmi & 100 & KJ677112 \\
\hline 29 & Chojnów & Ulmus minor & 3 & Ophiostoma novo-ulmi & 100 & KJ677112 \\
\hline 30 & Chojnów & Ulmus minor & 3 & Ophiostoma novo-ulmi & 99 & KJ677112 \\
\hline 31 & Dobieszyn & Ulmus laevis & 3 & Ophiostoma novo-ulmi & 100 & KJ677112 \\
\hline 32 & Grójec & Ulmus laevis & 2 & Ophiostoma novo-ulmi & 100 & KJ677112 \\
\hline \multirow{4}{*}{39} & \multirow{4}{*}{ Łopuchówko } & Ulmus laevis & 4 & Ophiostoma novo-ulmi & 100 & KJ677112 \\
\hline & & Ulmus minor & 3 & Ophiostoma novo-ulmi & 100 & KJ677112 \\
\hline & & Ulmus minor & 2 & Ophiostoma novo-ulmi & 99 & KJ677112 \\
\hline & & Ulmus minor & 2 & Ophiostoma novo-ulmi & 99 & KJ677112 \\
\hline
\end{tabular}


Table 3. Fungi isolated from elm branches

\begin{tabular}{|c|c|c|c|c|c|c|}
\hline Plot no. & Location & Host & Isolates no. & Molecular identification & $\begin{array}{c}\text { Probability } \\
\%\end{array}$ & $\begin{array}{c}\text { No of referring } \\
\text { sequence at NCBI }\end{array}$ \\
\hline 3 & Miękinia & Ulmus minor & 1 & Gibberella avenacea & 99 & EU255805 \\
\hline 17 & Piaski & Ulmus glabra & 1 & Gibberella avenacea & 99 & EU255805 \\
\hline \multirow{2}{*}{19} & \multirow{2}{*}{ Rudy } & \multirow{2}{*}{ Ulmus glabra } & 1 & Diaporthe eres & 100 & KJ210530 \\
\hline & & & 1 & Gibberella avenacea & 100 & JQ765664 \\
\hline 21 & Rudy & Ulmus laevis & 2 & Diaporthe eres & 99 & KC343073 \\
\hline 22 & Żmigród & Ulmus minor & 1 & Fusarium sambucinum & 99 & KM231813 \\
\hline 26 & Białowieża & Ulmus glabra & 1 & Diaporthe eres & 100 & KC343073 \\
\hline 28 & Zwierzyniec & Ulmus laevis & 1 & Diaporthe eres & 99 & KJ210518 \\
\hline \multirow{2}{*}{33} & \multirow{2}{*}{ Chojnów } & \multirow{2}{*}{ Ulmus minor } & 1 & Diaporthe melonis & 99 & JN032733 \\
\hline & & & 1 & Diaporthe eres & 99 & JQ765658 \\
\hline \multirow{6}{*}{39} & \multirow{6}{*}{ Łopuchówko } & \multirow{6}{*}{ Ulmus laevis } & 1 & Aureobasidium pullulans & 99 & JF440584 \\
\hline & & & 3 & Gibberella avenacea & 99 & EU255805 \\
\hline & & & 2 & Diaporthe eres & 99 & KC343073 \\
\hline & & & 2 & Diaporthe melonis & 99 & JN032733 \\
\hline & & & 1 & Nectria nigrescens & 99 & HQ897812 \\
\hline & & & 2 & Gibberella baccata & 99 & FN547471 \\
\hline
\end{tabular}

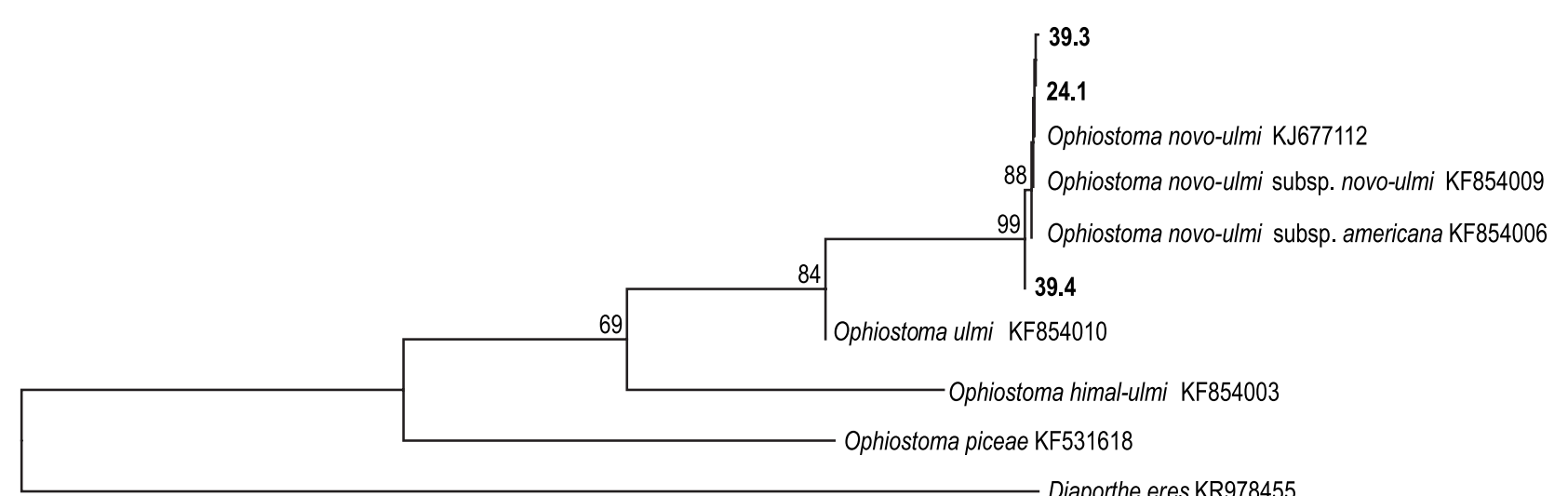

Diaporthe eres KR978455

0.5

Fig. 2. Phylogenetic tree of Ophiostoma novo-ulmi isolates

\section{Discussion}

Ten years ago the investigation of DED in Poland confirmed occurrence of $O$. ulmi and two subspecies of O. novo-ulmi: subsp. novo-ulmi and subsp. amerciana (Guździoł et al., 2004). In addition the authors found the occurrence of isolates called as fax-waxy, described earlier by Brasier et al. (1998). Przybył et al. (2006) showed that isolated of O. novo-ulmi and "fax-waxy" were more pathogenic then O. ulmi. Brasier \& Kirk (2010) found among 20 isolates collected from the Baltic Ports region of Poland in 1980 three exhibited the introgression of subsp. americana DNA.

Our study confirmed that O. novo-ulmi is the only Ophiostoma species isolated from diseased elms. Bartnik et al. (2015) also found that only O. novo-ulmi infested studied elms in four stands localized in Car- pathians (SE Poland). Only 30\% of elms didn't show a disease symptoms. Authors found that DED might play a significant role in promotion the appearance of a habitat suitable for a rare insect Rosalia longicorn (Rosalia alpina L.) within the species' range. In our study the symptoms intensity of infected elms differ from $5 \%$ to $70 \%$ of crown reduction, because of disease development. In addition only in 55\% of investigated branches the alive mycelium of $O$. novo-ulmi was found, what prove that the infestation of these elms took place at least two years earlier. In the rest cases the DED agent was replaced by the other fungi.

In this study there were no possibility to identified isolates to the subspecies level on the base of analyzing region and referring sequences deposit. Sequences were deposited in NCBI data base for this region as a subspecies. There were a few sequences, and it 
was difficult to compare, because there were no similar in whole its length. The differences between subspecies were based on occurrence additional nucleotide at the beginning or at the end of sequence. There were no differences in the shared part $670 \mathrm{pz}$ of these sequences and in addition these deposited sequences were not confirmed in paper or any morphological data of Ophiostoma subspecies cultures. There were no genetic diversity of Polish population in analyzed ITS region. Two isolates among 45 differed from the others but only in one or two nucleotides in DNA. Both were isolated from the same plot. On the base of culture morphology all our isolates were similar and we did not isolate a waxy cultures as Guźdizol et al. (2004) or Brasier et al. (1998). Similarly Santini et al. (2005) found that Italian elms were infected by both subspecies of O. novo-ulmi - novo-ulmi and americana and they didn't notice $O$. ulmi. Kirisits et al. (2001) noticed that O. ulmi disappeared from area of Austria. Most of the isolates, which they analyzed belonged to O. novo-ulmi and only few were described as a hybrid between O. ulmi and O. novo-ulmi. The hybrid between $O$. novo-ulmi subspecies occurrence was also suggested by Santini et al. (2005). In Spain O. ulmi as well as $O$. novo-ulmi subsp. novo-ulmi and subsp. americana were found on elms, moreover the occurrence of hybrids between species were confirmed (Solla et al., 2008). In other studies the genetic analysis recognized fragment of O. novo-ulmi subsp. americana DNA built in O. novo-ulmi subsp. novo-ulmi, what might have suggested that there was an hybrid between these subspecies (Konrad et al., 2002; Brasier \& Kirk, 2010). Brasier \& Kirk (2010) created a hypothesis of hybrid, that nowadays spread in Europe and could infest the elms as well as the parental pathogens. Elm resources in Poland were investigated on the base of forest service inventory lately (Napierała-Filipiak et al., 2014). They have noticed the increase of forest area dominated by elms since 1970's, the last inventory data (Głaz, 1986). Only in Sudety Mountains the decrease of elm population is visible. Data showed by authors might suggested the collapse of DED pandemic development. But in this study on many investigated stands and places with small elm groups both the diseased and healthy trees were observed. The DED agent is still present and common on the area of a whole country. Our observations confirm the previous data from Poland (Mańka et al., 1978) that U. minor is the most sever damaged by DED and the less U. laevis. Although in our study the number of isolates received from $U$. leavis was the highest, however, field studies suggest that this species prevails in the elm resources in Poland (Danielewicz, 2008; Filipiak \& Napierała-Filipiak, 2015; Napierała-Filipiak et al., 2016). Data provided by Peterken \& Mountford (1998) or Oheimb \& Brunet (2007) showed that DED was able to de- crease the elm population but very rarely cause the total elimination of this tree species. They observed the enhanced position of elm in stand, where the population decreased in the past. At the other hand there was a notice of decrease of DED on U. glabra in the north part of Norway and at the same time appearing the young generation of wych elm (Solheim et al., 2011). Other fungi species that were isolated from branches with DED symptoms belonged to the pathogen, weak pathogen, saprotrophs or even endotrophs. They colonized alive, dead or weekend tissue and alter O. novo-ulmi. For example a polyphagus species $D$. eres was described as pathogenic to more than 300 woody plant species, including Populus spp. Carpinus spp., Magnolia spp., Prunus persica (L.) Batsch, Rubus sp., Juglans cinerea L. and Vitis vinifera L. (Anagnostakis, 2007; Thomidis \& Michailides, 2009; Vrandečić et al., 2011; Kaliterna, et al., 2012). The fungi that colonized elm twigs and branches after O. novo-ulmi disappearance have been noted in some papers in Polish. Different species of Diaporthe, Nectria and some species of Fusarium were found in dead or dying trees of several deciduous species. Thirty one fungal species were found in dead oak branches. Among them Gibberella avenacea and Aureobasidium pullulans were identified (Kwaśna \& Siwecki 2002). Buttin and Kowalski (1986) investigated fungi that colonized dead twigs during natural pruning of branches of Acer pseudoplatanus L., Alnus glutinosa (L.) Gaertn., Betula pendula Roth, Carpinus betulus L. and Fraxinus excelsior L. Diaporthe spp., Fusarium sp. and Nectria spp. had been isolated from maple, birch, hornbeam and ash dead branches. Among several species of Ascomycota, Basidiomycota and Fungi imperfecti D. acerina (Peck) Sacc., D. carpini (Pers.) Fuckel, Fusarium stilboides Wollenw. (current name Gibberella stilboides W.L. Gordon ex C. Booth), N. cinnabarina (Tode) Fr. and N, episphaeria (Tode) Fr. (current name Dialonectria episphaeria (Tode) Cooke) were identifies. In particularly $D$. carpini was the most frequent species in hornbeam wood of dead twigs. Moreover Nectria radicicola Gerlach \& L. Nilsson (current name Ilyonectria radicicola (Gerlach \& L. Nilsson) P. Chaverri \& Salgado) was also one of species colonizing diseased or dead young Alnus inacana (L.) Moench in industrial area in southern Poland (Domański \& Kowalski, 1984) and in dead wood of oaks both in branches and trunks Fusarium solani (Mart.) Sacc. was one of several species that occupied necrotic tissue (Kowalski, 1991, 1996).

In conclusion the Ophiostioma novo-ulmi is the main agent of DED in Poland, and it seems that in spite of common pathogen occurrence in the country the existence of elms populations are not endangered. The population of O. novo-ulmi doesn't differ genetically. Ulmus minor is the most sensitive species to DED among elms occurring in Poland. 


\section{Acknowledgement}

This study was financially supported by the National Science Centre, Poland, grant No 2011/01/B/ NZ9/02883 "Assessment of the present population size, distribution, and condition of elms (Ulmus spp.) in Poland".

\section{References}

Anagnostakis SL (2007) Diaporthe eres (Phomopsis oblonga) as a pathogen of butternut (Juglans cinerea) in Connecticut. Plant Disease 91: 1198.

Bartnik C, Michalcewicz J \& Ciach M (2015) Dutch elm disease and the habitat of endangered Rosalia longicorn Rosalia alpina (L.): A conservation paradox? Polish Journal of Ecology 63: 440-447.

Brasier CM (1991) Ophiostoma novo-ulmi sp. nov., causative agent of current Dutch elm disease pandemics. Mycopathologia 115: 151-161.

Brasier CM (1996) New horizons in Dutch elm disease control: Report for Forest Research, HMSO, London, pp. 20-28.

Brasier CM \& Kirk SA (2001) Designation of the EAN and NAN races of Ophiostoma novoulmi as subspecies. Mycological Research 105: 547-554.

Brasier CM \& Kirk SA (2010) Rapid emergence of hybrids between the two subspecies of Ophiostoma novo-ulmi with a high level of pathogenic fitness. Plant Pathology 59: 186-199.

Brasier CM, Kirk SA, Pipe ND \& Buck KW (1998) Rare interspecific hybrids in natural populations of the Dutch elm disease pathogens Ophiostoma ulmi and O. novo-ulmi. Mycological Research 102: 45-57.

Buttin von H \& Kowalski T (1986) Die natürliche Astreiningung und ihre biologischen Voraussetzungen. III. Die Pilzflora von Ahorn, Erle, Birke, Hainbuche und Esche. European Journal of Forest Pathology 16: 129-138.

Danielewicz W (2008) Ekologiczne uwarunkowania zasięgów drzew i krzewów na aluwialnych obszarach doliny Odry. Wydawnictwo Uniwersytetu Przyrodniczego, Poznań.

Domański S \& Kowalski T (1984) O procesie chorobowym Alnus incana (L.) Mönch i udziale w nim grzybów patogenicznych na wybranych powierzchniach GOP. Reakcje biologiczne drzew na zanieczyszczenia przemysłowe. Materiały II Krajowego Sympozjum (ed. by R Siwecki) Wydawnictwo Naukowe Uniwersytetu im. Adama Mickiewicza, Poznań, pp. 289-294.

Faccoli M \& Battisti A (1997) Observations on the Transmission of Ophiostoma ulmi by the smaller elm bark beetles (Scolytus spp.): Proceedings of a IUFRO Meeting: Integrating cultural tactics into the management of bark beetle and reforestation pests (ed. by JC Grégoire, AM Liebhold, FM Stephen, KR Day \& SM Salom) USDA Forest Service General Technical Report NE-236, pp. 172-176.

Filipiak M \& Napierała-Filipiak A (2015) Zarys ekologii: Wiązy (ed. by W Bugała, A Boratyński \& G Iszkuło) Bogucki Wydawnictwo Naukowe, Poznań, pp. 133-181.

Gardes M \& Bruns TD (1993) ITS primers with enhanced specificity for Basidiomycetes - Application to the identification of mycorrhizae and rusts. Molecular Ecology 2: 113-118.

Głaz J (1986) Wiąz w Lasach Państwowych. Sylwan 130: 23-33.

Guździoł E, Przybył K \& Pałucha A (2004) Grzyby rodzaju Ophiostoma związane z holenderską choroba wiązów w Polsce: Choroby roślin na tle środowiska. 85 lat Fitopatologii w Wielkopolsce 50 lat Katedry Fitopatologii Leśnej. Konferencja Jubileuszowa, 18-19 listopada 2004, Poznań. (ed. by M Mańka \& Z Weber) 181.

Jacobi WR, Koski RD \& Negron JF (2013) Dutch elm disease pathogen transmission by the banded elm bark beetle Scolytus schevyrewi. Forest Pathology 43: 232-237.

Kaliterna J, Miličević T \& Cvjetković B (2012) Grapevine trunk diseases associated with fungi from the Diaporthaceae family in Croatian vineyards. Archives of Industrial Hygiene and Toxicology 63: 471-479.

Kirisits T, Krumbock S, Konrad H, Pennerstorfer J \& Halmschlager E (2001) Investigations on the occurrence of the Dutch elm disease pathogens in Austria. Forstwissenschaftliches Centralblatt vereinigt mit Tharandter forstliches Jahrbuch 120: 231-241.

Konrad H, Kirisits T, Riegler M, Halmschlager E \& Stauffer C (2002) Genetic evidence for natural hybridization between the Dutch elm disease pathogens Ophiostoma novo-ulmi ssp. novo-ulmi and Ophiostoma novo-ulmi ssp. americana. Plant Pathology 51: 78-84.

Kowalski T (1991) Oak decline: I. Fungi associated with various disease symptoms on overground portions of middle-aged and old oak (Quercus robus L.). European Journal of Forest Pathology 21: 136-151.

Kowalski T (1996) Występowanie grzybów w nekrotycznych tkankach pni i gałęzi Quercus robur L. zależnie od wieku. Materiały z Sympozjum "Nowe kierunki w fitopatologii”, Kraków 11-13 września 1996: 93-98.

Kwaśna H \& Siwecki R (2002) Przyczyny zamierania siewek i młodych szadzonek dębu w Nadleśnictwie Smolarz. Sylwan 146: 91-107.

Mańka K (2005) Fitopatologia Leśna. PWRiL, Warszawa. 
Mańka K, Bałązy S, Chwaliński K \& Michalski J (1978) Odporność wiązów w Poznaniu i okolicy na holenderską chorobę wiązu. Zeszyty Problemowe Postępów Nauk Rolniczych 198: 251-265.

Napierała-Filipiak A, Filipiak M \& Jaworek J (2014) Rozmieszczenie zasobów drzew $\mathrm{z}$ rodzaju wiąz (Ulmus spp.) w lasach Polski w świetle dokumentacji leśnej. Sylwan 158: 811-820.

Napierała-Filipiak A, Filipiak M, Łakomy P, Kuźmiński R \& Gubański J (2016) Changes in elm (Ulmus) populations of mid-western Poland during the past 35 years. Dendrobiology 76: 145-156.

Oheimb G \& Brunet J (2007) Dalby Soderskog revisited: Long-term vegetation changes in a south Swedish deciduous forest. Acta Oecologica 31: 229-242.

Peterken GF \& Mountford EP (1998) Long-term change in an unmanaged population of elm subjected to Dutch elm disease. Journal of Ecology 86: 205-218.

Przybył K, Dahm H, Ciesielska A \& Moliński K (2006) Cellulolytic activity and virulence of Ophiostoma ulmi and O-novo-ulmi isolates. Forest Pathology 36: 58-67.

Santini A, Montaghi A, Vendramin GG \& Capretti P (2005) Analysis of the Italian Dutch elm disease fungal population. Journal of Phytopathology 153: 73-79.

Solheim H, Eriksen R \& Hietala AM (2011) Dutch elm disease has currently a low incidence on wych elm in Norway. Forest Pathology 41: 182-188.
Solla A, Dacasa MC, Nasmith C, Hubbes M \& Gil L (2008) Analysis of Spanish populations of Ophiostoma ulmi and O. novo-ulmi using phenotypic characteristics and RAPD markers. Plant Pathology 57: 33-44.

Tamura K, Peterson D, Peterson N, Steche G, Nei M \& Kumar S (2011) MEGA 5: Molecular evolutionary genetics analysis using maximum likelihood, distance and parsimony methods. Molecular Biology and Evolution 28: 2731-2739.

Thomidis T \& Michailides TJ (2009) Studies on Diaporthe eres as a new pathogen of peach trees in Greece. Plant Disease 93: 1293-1297.

Thompson JD, Gibson TJ, Plewniak F, Jeanmougin F \& Higgins DG (1997) The CLUSTAL X windows interface: flexible strategies for multiple sequence alignment aided by quality analysis tools. Nucleic Acids Research 25: 4876-4882.

Webber JF (1990) Relative effectiveness of Scolytus scolytus, S. multistriatus, and S. kirschii as vectors of Dutch elm disease. European Journal of Forest Pathology 20: 184-192.

White TJ, Bruns T, Lee S \& Taylor JW (1990) Amplification and direct sequencing of fungal ribosomal RNA genes for phylogenetics: PCR Protocols: A guide to methods and applications (ed. by MA Innis, DH Gelfand, JJ Sninsky \& TJ White), Academic Press, San Diego, U.S.A., pp. 315-322.

Vrandečić K, Jurković D, Ćosić J, Postić J \& Riccioni L (2011) First report of cane blight on blackberry caused by Diaporthe eres in Croatia. Plant Disease 95: 612 . 